\title{
Purchase Decision Process of Domain .id
}

\author{
Mudji Sabar \\ Faculty of Economics and Business \\ Universitas Mercu Buana, Jakarta, Indonesia \\ mudji_sabar@yahoo.com
}

\begin{abstract}
This research is aimed to examine the influence of price and service quality towards brand image and its impact on the purchase decision process domain .id. The secondary data are derived from the statistical data of the users of ccTLD (country code Top Level Domain) mainly during the year 20142015. This is a survey research using a list of guided questionnaires to collect primary data. The Structural Equation Modeling (SEM) is employed as the data analytical methods in this research. The population of this research is the users of domain .id. This research applies convenience-sampling technique and the sample size is $\mathbf{3 8 5}$ respondents. This research uncovers that, simultaneously, price and service quality have significant influence on brand image of domain .id. Price has been proven to have greater contribution compared to the contribution of service quality on the value of brand image. Furthermore, it shows that price, service quality, and brand image simultaneously influence purchase decision process. In this case, service quality contributes the most on the value of purchase decision process of domain .id.
\end{abstract}

Keywords: price, service quality, brand image, and purchase decision process.

\section{INTRODUCTION}

Domain name is a unique name or a code name to facilitate the access to enter the website. Another way to enter the website is through the IP address (internet protocol address). For example, to enter the Google searching machine, users should write down the IP address, namely IP 173.194.39.19. This IP address is much more difficult to memorize or less practical to use compared to the domain name of Google which is google.co.id. Thus, domain name is much more preferable than the IP address.

There are 2 top-level domain names known in the world, i.e. Top Level Domain (TLD) referring to international or global domain and country code Top Level Domain (ccTLD) referring to a specific country name. There are now hundreds of top-level domain names in the world, either TLD or ccTLD, that have been assigned by ICANN (Internet Corporation for Assigned Names and Numbers), the official regulator of domain name in the world.

As a country with a huge population and high penetration of internet user, the need to have a domain name referring to a country name of Indonesia is now becoming more and more important. According to e-Marketer, a Market Research Institution, the total internet users in Indonesia in 2014 was 83.7 million users. In 2016, this number is predicted to reach 102.8 million users and in 2017 it will be 112.6 million users. Now, Indonesia is the sixth big internet users in the world [1]. The evidence will consequently encourage the development of virtual businesses in Indonesia. Manual works related to business conduct nowadays are mostly done virtually through the internet media.

This is in line with the need to introduce the existence of business entity as well as to market the products and services by companies registered in Indonesia through electronic facilities. The domain name highly expected by business entities in Indonesia is the domain name representing Indonesia country name. Domain .id is known as an official domain country code name for Indonesia, as id symbolizes Indonesia. In terms of national currency, it is internationally known that Indonesian currency is IDR meaning the Indonesian Rupiah. Whereas RM is for Malaysian Ringgit, USD is for formal currency of the United States of America, and GBP is for Great Britain Pound sterling, the currency of England, etc.

The number of domain .id in Indonesia is now 13 domain names, i.e.: .co.id, .web.id, .sch.id, .or.id, .ac.id, .net.id, .mil.id, .biz.id, .my.id, .desa.id, .ponpes.id, and .id [2]. Domain .id was officially launched on August 17, 2014 at the 69th commemoration of the Indonesian Independence Day. The official regulator of domain .id is named PANDI, the abbreviation of Pengelola Nama Domain Indonesia - the official regulator of domain name Indonesia. Before domain .id was launched, PANDI had only introduced the Second Level Domain (SLD), i.e. .co.id, .web.id, .sch.id, .or.id, .go.id, .ac.id, .net.id, .mil.id, .biz.id, .my.id, .desa.id.

Now, any party, individual or institutional, is able to own the first level domain .id, which symbolizes the country identity of Indonesia. In addition, people prefer to have the first level domain rather than the second level domain, such as .co.id, .go.id, .web.id, etc. As well, domain .id is more favorable because it represents the identity of the country name of Indonesia. Thus, domain .id is much more preferable than other domain names, especially for Indonesian business entities.

Domain .id has not only become a new alternative, but has also become the most potential competitor for former first level domain names, such as .com, which does not symbolize the country identity of Indonesia. It is quite possible that people or companies in Indonesia who formerly use domain .com would like to migrate to domain .id. Statistically, domain .id has experienced significant increase in 2015 as shown by the following table. 
TABLE I. USERS OF CCTLD IN INDONESIA IN 2015

\begin{tabular}{llllllllll}
\hline Domain & Jan. & Feb. & March. & Apr. & May & June & July & Aug. & Sept. \\
\hline .co.id & 58,701 & 59,563 & 60,537 & 61,316 & 62,092 & 62,685 & 63,896 & 64,598 & 65,189 \\
.web.id & 24,426 & 24,018 & 23,913 & 23,749 & 23,624 & 24,248 & 24,854 & 24,188 & 23,435 \\
.id & 8,529 & 9,287 & 11,087 & 12,404 & 13,709 & 14,610 & 15,328 & 16,747 & 17,802 \\
.sch.id & 14,250 & 13,661 & 13,825 & 14,048 & 14,287 & 14,482 & 14,781 & 14,842 & 14,918 \\
.my.id & 2,614 & 2,580 & 6,225 & 7,352 & 8,000 & 9,300 & 9,437 & 9,502 & 9,561 \\
.or.id & 5,871 & 5,927 & 5,980 & 6,030 & 6,091 & 6,117 & 6,290 & 6,344 & 6,376 \\
.ac.id & 3,397 & 3,435 & 3,457 & 3,486 & 3,513 & 3,523 & 3,576 & 3,589 & 3,614 \\
.go.id & 3,390 & 3,404 & 3,417 & 3,434 & 3,450 & 3,471 & 3,490 & 3,510 & 3,530 \\
.desa.id & 1,243 & 1,291 & 1,513 & 1,942 & 2,169 & 2,217 & 2,239 & 2,252 & 2,255 \\
.biz.id & 905 & 894 & 884 & 904 & 908 & 910 & 949 & 954 & 975 \\
.net.id & 375 & 379 & 386 & 385 & 387 & 386 & 389 & 391 & 391 \\
.mil.id & 259 & 261 & 264 & 267 & 267 & 268 & 270 & 272 & 273 \\
.ponpes.id & - & - & - & 19 & 19 & 19 & 57 & 57 & 57 \\
\hline Total & 123,960 & 124,700 & 131,488 & 135,336 & 138,516 & 142,236 & 145,556 & 147,246 & 148,376 \\
\hline
\end{tabular}

Table I shows that domain .id reaches the third position in September 2015 with the total number of 17,802 domain users. Domain .co.id remains the first with 65,189 users and domain .web.id the second with 23,435 users. Other 10 domains are under the position of domain .id. On the other hand, the users of domain .id have grown by $9.66 \%$ monthly since its official launching in 2014. This position is the fourth among the 13 domain names. The next position of monthly growth are occupied by .my.id $(5.22 \%)$, .or.id $(4.45 \%)$, .ac.id $(2.55 \%)$, go.id $(2.51 \%)$, desa.id $(1.38 \%)$, biz.id $(0.67 \%)$, .net.id $(0.28 \%)$, .mil.id $(0.19 \%)$, .ponpes.id $(0.03 \%)$. The top three positions are occupied by .co.id with the average monthly growth $45.14 \%$ (the first position), .web.id $17.49 \%$ (the second position), and .sch.id $10.43 \%$ (the third position).

At the end of September 2015, the total number of the users of domain .id is 148,376 users. Whereas the total users of international TLD registered in Indonesia is 285,020 users, almost twice of the total users of domain .id in Indonesia. The proportion of the total number of the users of domain .id is only $6.25 \%$ compared to the users of international TLD. However, domain .id is much more preferable as its name symbolizes country code identity of Indonesia.

The description above shows that domain .id has a unique phenomenon. Within less than 2 years, it occupied the third position in the domain market in Indonesia. Moreover, soon after its official launching it had already registered 5,004 domain users. Besides, the price and the brand image of domain .id are considered to have a unique influence for its market growth in Indonesia. It is noted that domain .id is the most expensive ccTLD in Indonesia. Table II below shows the price of each domain names in Indonesia in 2015.

TABLE II. THE PRICE OF CCTLD IN INDONESIA (IDR)

\begin{tabular}{lllll}
\hline No. & Domain Name & Registration & Transfer & Extension \\
\hline 1. & .id & 550,000 & 550,000 & 550,000 \\
2. & .co.id & 110,000 & 110,000 & 110,000 \\
3. & .ac.id & 55,000 & 55,000 & 55,000 \\
4. & .or.id & 55,000 & 55,000 & 55,000 \\
5. & .sch.id & 55,000 & 55,000 & 55,000 \\
6. & .web.id & 55,000 & 55,000 & 55,000 \\
7. & .my.id & 55,000 & 55,000 & 55,000 \\
8. & .biz.id & 55,000 & 55,000 & 55,000 \\
9. & .desa.id & 55,000 & 55,000 & 55,000 \\
\hline
\end{tabular}

b. Source: http://www.pandi.id/content/statistics, accessed October 14, 2015

In addition, domain .id was just newly launched by PANDI. However, it grew faster than the most of the domain names registered by PANDI. This evidence has indicated a unique relationship among the price, brand name, and the growth of the domain .id. 
PRESS

Ashton, Ann S., et.al. [3] mentioned that perceived value influence the intention to purchase (ITP). Perceived value consists of 3 elements, which are perceived brand image, perceived quality, and perceived sacrifice (monetary and nonmonetary price). Hence, it can be speculated that the fast growing of domain .id was triggered by perceived brand image, perceived quality, and perceived sacrifice. On the other hand, Zhang, Y (2015) supported the evidence that brand image influences the consumer behavior [4]

Another factor that may influence consumer behavior is service quality. Zeithaml, Valarie A, et.al. (1996) said that service quality has an impact on certain behavior indicating whether consumers will remain loyal or will leave the company or the service provider. Better service quality will result on favorable intention then favorable decision to purchase goods or services [5].

Accordingly, a field study investigating the influence of price and service quality towards brand image and its impact on the purchase decision process is necessary to conduct.

\section{LITERATURE REVIEW}

Tjiptono (2008) defined that price is a monetary measurement functioning as a transaction instrument to obtain goods or services [6]. Price has a positive influence on the profit of any business. Lichtenstein, Donald R., et.al. (1993) formulated 5 dimensions of price, which are price awareness, physical awareness of the product, discounted price, price scheme, and prestige of the price [7]. This research applies only 3 suitable dimensions of price for domain .id, i.e price awareness, discounted price, and price scheme. Physical awareness of the product is excluded in this research because domain .id relates to services instead of goods. The prestige of the price is also eliminated, as this value is already included in brand image.

Parasuraman, A. et.al. (1995) said that service quality has an important role to the customer satisfaction. This is as just the same as the influence of product quality (in term of goods) to customer satisfaction. In addition, Parasuraman has formulated 5 dimensions to measure the service quality, i.e. tangible, empathy, responsiveness, reliability, and assurance [8].

Kotler and Amstrong (2008) defined brand as a valuable asset for the product or company. Brand can also function as an instrument to differentiate its products or services from the products or services of the competitors. Brand is a uniqueness owned by the product used to win the competition. Strong brand can create higher price of the product as well. Thus, brand with a strong equity is really a valuable asset for the products or services. Moreover, there are 6 dimensions to measure brand image, which are memorable, meaningful, likeable, transferable, adaptable, and protectable [9].

Purchase decision process is usually defined as stages to take by the consumers to determine their willingness or their decision whether to consume or not to consume the products or the services offered to them. In this case, the Engle, Kollat and Blackwell (EKB) Model formulate 5 steps [10]. First is the problem or need recognition to be identified by the consumers. In certain situation, the consumers feel in mind of buying some products or consuming some services. Second, the consumers search for alternatives from some possible resources to fulfill their need. Here, adequate information should be collected and analyzed. Third is the evaluation of these alternatives to choose the products or services. In doing this process, the consumers may consider aspects such as personal aspects (personalities, preferences, experiences, etc.), social influences (family members, friends, media, etc.), as well as the benefit or the suitability of the products or services available. Fourth, the consumers determine their choice followed directly by their consumption of the products or services. Fifth, they make post evaluation after using the products or services. Here, they identify whether they are satisfied or not with the products or services they have already used. The Theory of Planned Behavior mentions that the intentions play as central factors to perform behavior. The intentions are basically determined by motivational factors. First is attitude towards the behavior (whether they like or not). Second is subjective norms, i.e. individual's beliefs, cultures, etc. Third is perceived behavioral control, i.e. such an evaluation of the probability of success to fulfill their expectancies. The greater the probability, the greater the chance to perform the behavior will be [11].

There are 2 hypotheses developed to facilitate the test of the field finding of the research. They are as follows:

Hypothesis 1: Price and service quality influence brand image of domain .id.

Hypothesis 2: Service quality, price, and brand image influence purchase decision process of domain .id.

\section{RESEARCH METHODOLOGY}

This research applied the survey methods done in November and December 2015. There are 5 variables used in this research, i.e. price and service quality as independent variables, brand image as an intervening variable, and purchase decision process as a dependent variable. The population of this research is the users of domain .id. Using Lemeshow formula (2) with $\mathrm{z}=1.960, \mathrm{P}=0.5$ and $\mathrm{e}=0.10$, the sample size of the research is 384.16 respondents then rounded up to become 385 respondents [12]. The convenience sampling technique is applied in this research. The respondents are anybody available in the location where this research was done who met the sampling criteria, i.e. the users of domain .id and willing to fulfill the research questionnaires.

This research applied SEM technique to analyze the primary data. This technique is considered suitable as there is an intervening variable and the sample size is big enough which more than 100 respondents. In addition, the research variables are all latent variables that cannot be directly measured [13]. Figure 1 shows the structural model (SEM Model) of the influence of price and service quality towards brand image and its impact on the purchase decision process domain .id 


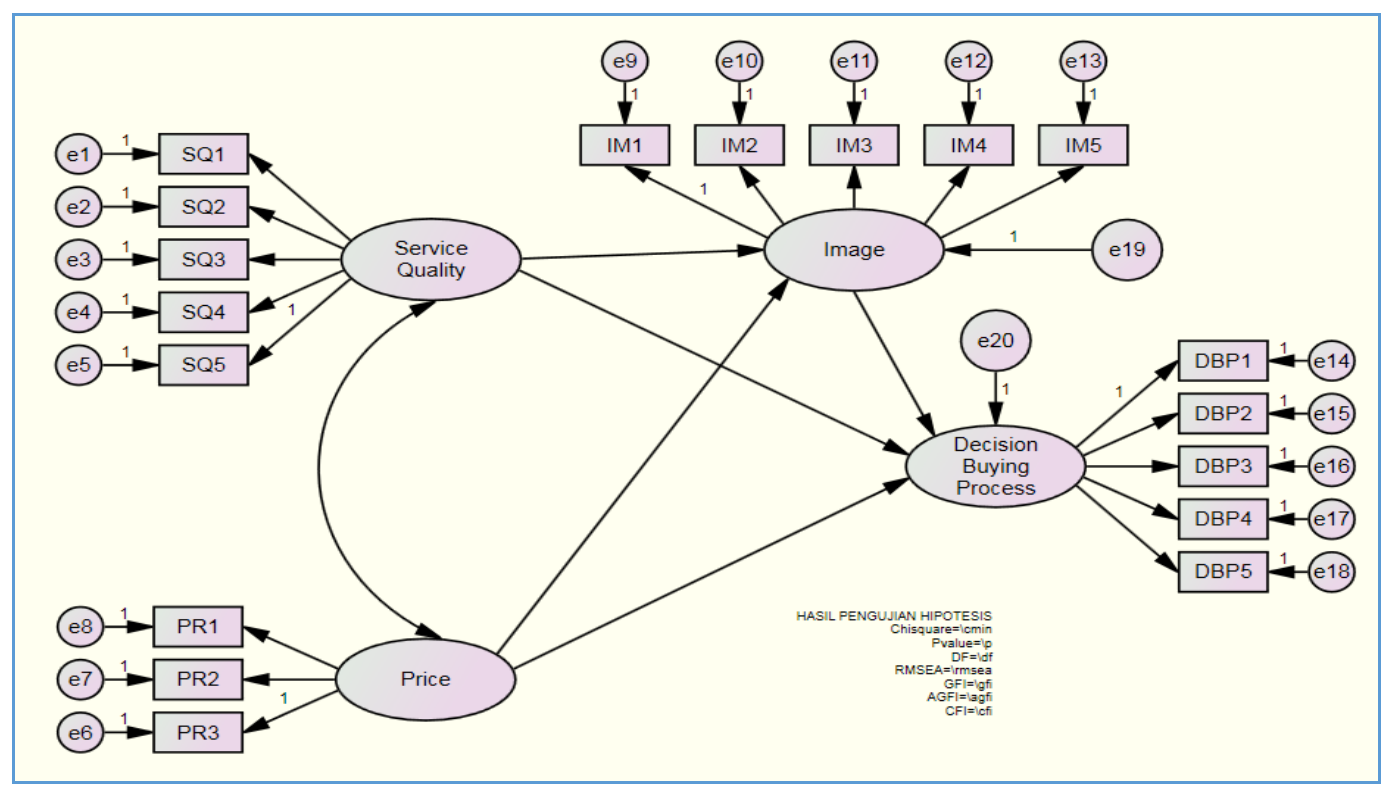

Fig. 1. The Structural Model of the Influence of Price and Service Quality towards Brand Image and its Impact on the Purchase Decision Process Domain .id

\section{RESEARCH FINDINGS AND DISCUSSIONS}

\section{A. Overall Model Fit}

Based on the Goodness of Fit (GOF) Test, it is known that the overall model is fit as 3 out of 4 criteria of GOF are fit [14]. The following table shows this evidence.

TABLE III. RESEARCH MODEL TEST

\begin{tabular}{lcll}
\hline Criteria of GOF & The Result & Cut Off Value & Conclusion \\
\hline P-value & 0.000 & $\geq 0.050$ & Not Fit \\
RMSEA & 0.069 & $\leq 0.080$ & Fit \\
GFI & 0.902 & $\geq 0.900$ & Fit \\
C FI & 0.949 & $\geq 0.900$ & Fit \\
\hline
\end{tabular}

Based on Table III, it is shown that the p-value is 0.000 (< $0.05)$. This indicates that the model is not fit. The RMSEA is identified $0.069(<0.08)$. This result shows that the model is fit with the data. Furthermore, the result proves that both GFI (0.902) and CFI (0.949) are also fit, as their values meet the requirement of Cut Off Value $(\geq 0.90)$.

\section{B. Measurement Model Fit}

The result of Measurement Model Fit is shown on the Table IV below.

TABLE IV. The MeAsurement Model Fit

\begin{tabular}{|c|c|c|c|c|c|c|}
\hline \multicolumn{3}{|c|}{ Measurement Model } & \multicolumn{2}{|c|}{ Estimate } & \multirow[t]{2}{*}{ Error } & \multirow[t]{2}{*}{$\mathrm{P}$} \\
\hline & & & $R W$ & $S R W$ & & \\
\hline SQ1 & $\begin{array}{l}<-- \\
\end{array}$ & SQ & 0.889 & 0.73 & 0.54 & **** \\
\hline SQ2 & $<--$ & SQ & 0.951 & 0.79 & 0.63 & $* * *$ \\
\hline SQ3 & $<---$ & SQ & 0.984 & 0.81 & 0.66 & $* * *$ \\
\hline SQ4 & $<---$ & SQ & 0.906 & 0.74 & 0.65 & $* * *$ \\
\hline SQ5 & $<---$ & SQ & 1.000 & 0.78 & 0.61 & **** \\
\hline PR1 & $<---$ & PR & 0.900 & 0.77 & 0.60 & $* * *$ \\
\hline
\end{tabular}




\begin{tabular}{lclllll}
\hline \multicolumn{2}{l}{ Table IV Cont.... } & & & & & \\
\hline PR2 & $<---$ & PR & 0.900 & 0.82 & 0.67 & $* * *$ \\
PR3 & $<---$ & PR & 1.000 & 0.82 & 0.69 & $* * *$ \\
BI1 & $<---$ & BI & 1.000 & 0.79 & 0.63 & $* * *$ \\
BI2 & $<---$ & BI & 0.970 & 0.70 & 0.50 & $* * *$ \\
BI3 & $<---$ & BI & 0.980 & 0.80 & 0.64 & $* * *$ \\
BI4 & $<---$ & BI & 0.970 & 0.77 & 0.59 & $* * *$ \\
BI5 & $<---$ & BI & 1.010 & 0.77 & 0.59 & $* * *$ \\
PDP1 & $<---$ & PDP & 1.000 & 0.79 & 0.54 & $* * *$ \\
PDP2 & $<---$ & PDP & 0.970 & 0.70 & 0.50 & $* * *$ \\
PDP3 & $<---$ & PDP & 0.980 & 0.80 & 0.48 & $* * *$ \\
PDP4 & $<---$ & PDP & 0.970 & 0.77 & 0.46 & $* * *$ \\
PDP5 & $<---$ & PDP & 1.010 & 0.77 & 0.57 & $* * *$ \\
\hline
\end{tabular}

Based on Table IV, it can be concluded that all indicators of all variables are fit as their loading factors (SRW) are all above their errors with the p-value $<0.05(* * *)$.

\section{Structural Model Fit}

The analysis of Structural Model is really the evaluation of parameters of the causal relationship of one latent variable to another latent variable. The Figure 2 shows the parameter estimation of standardized loading factors.

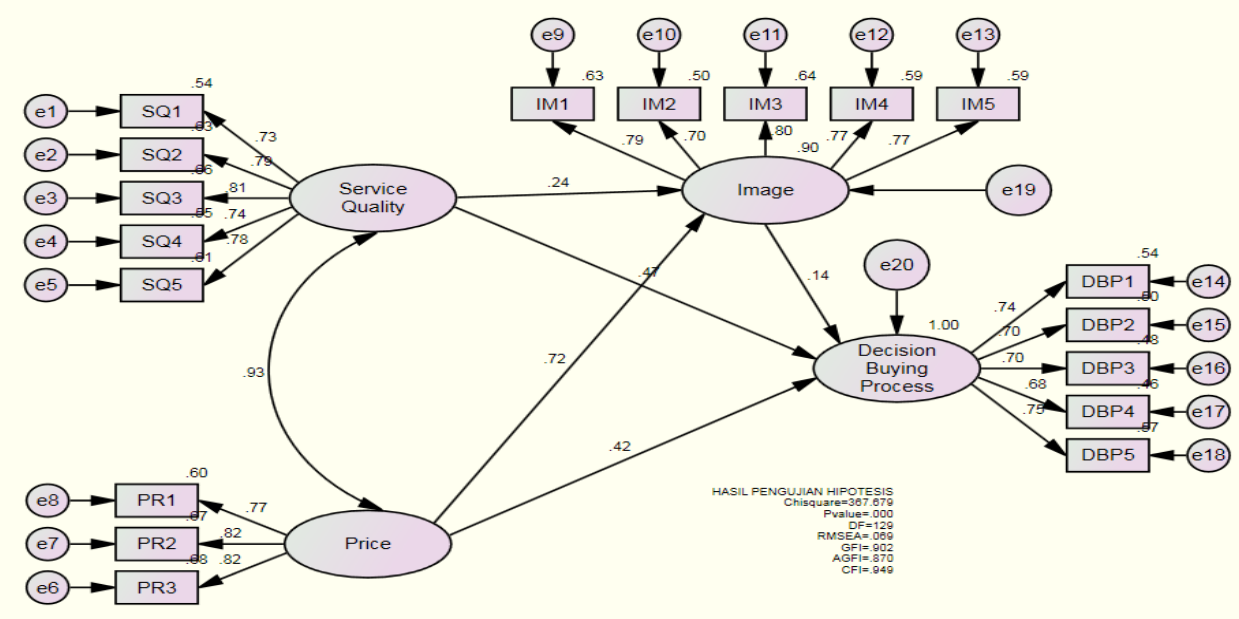

Fig. 2. Structural Model

Based on Figure 2, the parameter estimation of the Structural Model can be identified, the result of which is summarized on the Table $\mathrm{V}$ below.

TABLE V. SUMmary OF THE RESUlt OF PARAMETER ESTIMATION OF STRUCTURAL MOdEL

\begin{tabular}{|c|c|c|c|c|c|c|c|c|}
\hline & & & \multicolumn{2}{|c|}{ Estimate } & \multirow{2}{*}{ S.E. } & \multirow{2}{*}{ C.R. } & \multirow{2}{*}{$\mathrm{P}$} & \multirow{2}{*}{$\mathrm{R} 2$} \\
\hline & & & $R W$ & $S R W$ & & & & \\
\hline Brand Image & $<-$ & Service Quality & 0.244 & 0.242 & 0.155 & 1.573 & 0.016 & $53,42 \%$ \\
\hline Brand Image & $<--$ & Price & 0.689 & 0.718 & 0.151 & 4.560 & $* * *$ & \\
\hline Purchase Decision Process & $<-$ & Service Quality & 0.489 & 0.465 & 0.130 & 3.756 & $* * *$ & $56,88 \%$ \\
\hline Purchase Decision Process & $<--$ & Price & 0.423 & 0.422 & 0.190 & 2.230 & 0.026 & \\
\hline Purchase Decision Process & $<--$ & Brand Image & 0.144 & 0.138 & 0.157 & 0.915 & 0.006 & \\
\hline
\end{tabular}

Hypothesis 1: The influence of price and service quality towards brand image.

The hypothesis test shows that price and service quality positively influence brand image. This can be proven from the fact that path coefficient $(\mathrm{SRW})>0$ with the p-value $<0.05$. Price and service quality simultaneously contribute as big as
$53.42 \%$ to the value of brand image where the bigger contribution derives from price, which is $47.47 \%$.

This finding shows that price strongly influences the value of brand image of domain .id. Table II identifies that the price of domain .id is the most expensive domain name among ccTLDs in Indonesia. This is five times of the price of domain .co.id, which is only IDR 110,000 . When compared to 7 other 
domain names or other ccTLDs in Indonesia, the price of domain .id is ten times of the price of each of the 7 other domain names, which is only IDR 55,000 each.

This evidence indicates that the users of domain .id consider that the price of domain .id represents its brand image as a country code domain name of Indonesia. They perceived the price not only in term of monetary but also on non-monetary perspective as well. This is in line with the understanding of Ashton, Ann S. et.al. 2010 that the indicators of perceived sacrifice consists of monetary price and nonmonetary price [15]. In term of non-monetary perspective, the users might think that domain .id makes their business easier to notice by their customers. Thus, this is a considerable sacrifice they have to make. Therefore, they do not mind with the expensive price of domain .id. Accordingly, it is necessary for not decrease this price as far as the quality of domain .id is still good in mind of the users. In this case, the price awareness and price scheme dimensions should be continually maintained by the management to ensure the value of brand image of domain .id.

Hypothesis 2: The influence of service quality, price and brand image towards purchase decision process.

The finding shows that service quality, price and brand image positively influence purchase decision process. This can be proven from the fact that the path coefficient (SRW) $>$ 0 with p-value $<0.05$. The simultaneous influence of service quality, price and brand image contribute as big as $56.88 \%$ to the variability of purchase decision process. In this case, the biggest contribution is identified coming from service quality, which is as big as $27.56 \%$.

This finding shows that service quality plays as an important determinant for the process of purchase decision of domain .id. The better the service quality, the stronger the probability to buy domain .id will be. This evidence supports the thesis of Zeithaml, Valarie A. et.al (1996) that service quality has an impact on the particular consumer behavior [16]. In line with the role of price in contributing to the value of brand image, the quality of the services of domain id strengthens the willingness of the people to buy domain iid. Therefore, the service quality should be properly maintained to guarantee the performance of purchase decision in the future. Quick response to any problem faced by the users is necessary to maintain in daily services to keep the loyalty of the users of domain .id.

\section{CONCLUSION AND SUGGESTIONS}

Based on the description of the research findings, it can be concluded that price and service quality influence brand image. In this context, the influence of price is proven higher than the influence of service quality towards brand image. Price, service quality, and brand image simultaneously influence the purchase decision process of domain .id. Hence, the influence of service quality is the highest compared to the influence of price as well as the influence of brand image towards purchase decision process of domain .id. Conclusively, there are two key variables to maintain, i.e. the quality of price and the service quality of domain .id.

Accordingly, it is recommended that these two key variables should be properly maintained and improved for the better performance of purchase decision process of domain id in the future. The price should be creatively designed to attract and persuade the willingness of people to buy domain .id. In addition, dimensions that contribute strongly to the performance of service quality should also be properly maintained and increased along the daily operation of domain .id. Among others, the quick response to any complaint of the users should be well managed by the management. Shortly, the management should apply the mentioned recommendations as the strategic actions to improve the people's willingness to buy domain .id and to keep the loyalty of the existing users.

\section{ACKNOWLEDGEMENT}

First of all, I would like to acknowledge the work of Kristiurman Jaya Mendrofa in assisting the completion of this study, particularly in data collecting, both secondary and primary data. Second, I would genuinely like to thank my wife, Hartik Aningsih, and my children for their never-ending support. Without them, this research would not have been possible to carry through. Still, the content of this study's report remains the responsibility of the author.

\section{REFFERENCES}

[1] http://tekno.kompas.com/read/2014/11/24/07430087.

[2] http://www.pandi.id/content/statistics.

[3] Ashton, Ann Suwaree, Scott, Noel, Solnet, David, Breakey, Noreen 2010. Hotel restaurant dining : The relationship between perceived value and intention to purchase. Tourism and Hospitality Research, Vol. 10, No. 3 (JULY 2010), pp. 206-218.

[4] Zhang, Yi. 2015. The Impact of Brand Image on Consumer Behavior : A Literature Review. Open Journal of Business and Management, 2015, 3, 58-62. http://dx.doi.org/10.4236/ojbm.2015.31006.

[5] Zeithaml, Valarie A., Berry, Leonard L., Parasuraman, A. 1996. The Behavioral Consequences of Service Quality. Journal of Marketing, Vol. 60, No. 2 (April 1996), pp. 31-46.

[6] Tjiptono, Fandi. 2008. Edisi III. Strategi Pemasaran. Penerbit Andi. Yogyakarta.

[7] Lichtenstein, Donald. R., Ridgway, Nancy M., Netemeyer, Richard G.1993. Price Perception and Consumer Shopping Behavior: A Field Study. Journal of Marketing Research, Vol. 30, No. 2, May 1993, pp. $234-245$.

[8] Parasuraman, A., Berry, Leonard L., Zeithaml, Valarie A. 1995. 8th Ed. Marketing Classics: A Selections of Influential Articles. Prentice Hall International, Inc. New Jersey.

[9] Kotler, Philip, Amstrong, Gary. 2008. Prinsip-prinsip Pemasaran. Alih Bahasa Imam Nurmawan. Edisi 12. Erlangga. Jakarta

[10] Tan, Caroline Suelin. 2010. Understanding Consumer Purchase Behavior in the Japanese Personal Grooming Sector. Journal of Yasar University 201017 (5). pp. 2821-2831.

[11] Ajzen, Icek. 1991. The Theory of Planned Behavior. Academic Press. Inc.

[12] Lemeshow, Stanley, Hosmer Jr., David W., Klar, Janelle, and Lwanga, Stephen K. 1990. Adequacy of Sample Size in Health Studies. Published on behalf of World Health Organization. John Wiley \& Sons. New York.

[13] Haryono, Siswoyo, Wardoyo, Parwoto. 2012. Structural Equation Modeling. Intermedia Personalia Utama. Jakarta.

[14] Malhotra, Naresh K. 2007. 5 $5^{\text {th }}$ Edition. Marketing Research: An Applied Orientation, Pearson Education, Inc., New Jersey, USA.

[15] Ashton, Ann Suwaree, Scott, Noel, Solnet, David, Breakey, Noreen. 2010. Hotel restaurant dining : The relationship between perceived value and intention to purchase. Tourism and Hospitality Research, Vol. 10, No. 3 (JULY 2010), pp. 206-218.

[16] Zeithaml, Valarie A., Berry, Leonard L., Parasuraman, A. 1996. The Behavioral Consequences of Service Quality. Journal of Marketing, Vol. 60, No. 2 (April 1996), pp. 31-46. 